\title{
Regime de colaboração na política de formação de professores alfabetizadores: limites para a gestão democrática
}

\section{Regime of collaboration in the policy of the training of literacy teachers: limits for democratic management}

\author{
Régimen de colaboración en la política de formación de \\ profesores alfabetizadores: límites para la gestión democrática
}

\author{
Cleonara Maria Schwartz \\ (iD https://orcid.org/0000-0003-4411-2234 \\ Gildo Lyone Antunes de Oliveira \\ (iD) https://orcid.org/0000-0001-5754-7056 \\ Fernanda Zanetti Becalli \\ (iD) $h$ ttps://orcid.org/0000-0002-8628-6550
}

\begin{abstract}
Resumo: O artigo analisa a experiência implementada, nos anos de 2017 e 2018, no Espírito Santo, para operacionalizar a colaboração entre estado e os municípios para melhoria da aprendizagem na alfabetização. A partir de pesquisa bibliográfico-documental, constituiu-se um corpus de documentos que foram analisados tomando com referência a perspectiva dialógica e, teoricamente, se embasando nos conceitos de enunciado, texto, dialogia formulados pelo círculo de Bakhtin (2003; 2004). Os documentos analisados permitiram concluir que o atual ordenamento jurídico educacional possibilita que regimes de colaboração possam assumir funções reguladoras e centralizadoras de gestão do processo educacional desde a sala de aula até as instâncias responsáveis pela organização sistêmica da educação, contribuindo para a constituição de relações de subordinação dos municípios ao estado.
\end{abstract}

Palavras chaves: Regime de Colaboração. Gestão Democrática. Política Educacional. Alfabetização.

Abstracts: The article analyzes the experience implemented in the years 2017 and 2018, in Espírito Santo, to operationalize the collaboration between state and municipalities to improve learning in literacy. From a bibliographical-documentary research, a corpus of documents was constituted that were analyzed with reference to the dialogical perspective and, theoretically, based on the concepts of utterance, text, dialogue formulated by Bakhtin's circle $(2003 ; 2004)$. The documents analyzed allowed us to conclude that the current legal legal framework allows collaboration schemes to assume regulatory and centralizing functions of educational process management from the classroom to the bodies responsible for the systemic organization of education, contributing to the formation of subordination relationships from the municipalities to the state. 
Key words: Collaboration Regime. Democratic management. Educational politics. Literacy.

Resumen: El artículo analiza la experiencia implementada, en los años 2017 y 2018, en Espírito Santo, para operacionalizar la colaboración entre estado y los municipios para mejorar el aprendizaje en la alfabetización. A partir de la investigación bibliográfico-documental, se constituyó un corpus de documentos que fueron analizados tomando como referencia la perspectiva dialógica y, teóricamente, basándose en los conceptos de enunciado, texto, dialogia formulados por el círculo de Bakhtin (2003; 2004). Los documentos analizados permitieron concluir que el actual ordenamiento jurídico educativo posibilita que regímenes de colaboración puedan asumir funciones reguladoras y centralizadoras de gestión del proceso educativo desde el aula hasta las instancias responsables de la organización sistémica de la educación, contribuyendo a la constitución de relaciones de subordinación de los municipios al estado.

Palabras claves: Régimen de Colaboración. Gestión Democrática. Política Educativa. Alfabetización.

\section{Introdução}

No prefácio da obra intitulada Educação e federalismo no Brasil: combater desigualdades, garantir a diversidade, organizada por Oliveira e Santana (2010), chancelada pela Representação no Brasil da Organização das Nações Unidas para a Educação, a Ciência e a Cultura (Unesco), Vincent Defourny relata que a discussão dos impactos do federalismo na oferta educacional deve ter como perspectiva a "[...] consolidação da democracia, o fortalecimento do estado do direito e a construção de patamares mais elevados de justiça social [...]"(Defourny, 2010, p.7). Dentre as questões que Defourny considera como emergentes, no contexto dessa discussão, levando em conta os princípios que orientam a ação da Unesco no mundo, está a demanda por ampliação da participação dos cidadãos. Para Defourny (2010), discutir esse aspecto reforça "[...] o compromisso da UNESCO com o fortalecimento de um espaço público democrático [...]" (Defourny, 2010, p.7).

No entanto, vários autores (BONAMINO, 2003; DOURADO, 2013; CURY, 2011; SOUSA e CASTRO, 2017), por sua vez, têm mostrado a complexidade que envolve ações compartilhadas entre as diferentes esferas administrativas públicas para garantia de uma educação de qualidade e com equidade, no contexto de diversidades regionais do Brasil, o que parece tornar mais árdua a tarefa de se pensar no federalismo brasileiro formas de colaboração que contemplem a participação de diferentes sujeitos que atuam em diversas instâncias nas políticas educacionais.

Segundo Souza e Faria (2004), se, por um lado, a Constituição Federal de 1988 (CF/1988) reconheceu a educação como um direito social e a operacionalização desse direito como devendo ocorrer por meio de um federalismo cooperativo a ser efetivado pelo regime de colaboração, por outro lado, também exigiu que se desse conta de formas de associação e organização que unissem diferentes políticas dentro de um sistema político mais abrangente. 
Nesse contexto, de acordo com Sousa e Castro (2017), a implementação de um federalismo cooperativo deveria adotar medidas que pudessem ser pensadas e implementadas por meio de negociações de forma que os diferentes membros pudessem compartiIhar o processo de produção e execução das decisões. Vale considerar que o processo de descentralização administrativa e fiscal marcado pela CF/1988 clama por constituição de relações intergovernamentais que envolvam maior articulação entre as esferas públicas administrativas, uma vez que o artigo 211 definiu como incumbência principal dos Municípios o ensino fundamental e a educação infantil, para os Estados e o Distrito Federal, o ensino fundamental e médio, e, para a União, a organização do sistema federal e dos Territórios, tendo também a função redistributiva e supletiva, garantido a equalização de oportunidades educacionais entre os entes federados.

Conforme pontua Bonamino (2003), esse processo de descentralização buscou reduzir as responsabilidades federais no tocante as questões de fim social, como o ensino, atender a interesses políticos das elites locais que reivindicavam a ampliação de seus espaços no poder, diminuídos pela centralização política ditatorial, e atender a movimentos sociais e grupos de esquerda, que concebiam a descentralização como democratização das ações do governo. Apesar disso, Cunha (1995) alertava para a complexidade que envolveria o estabelecimento de regimes de colaboração, principalmente, levando-se em conta que algumas cidades mais pobres não tiveram autonomia alguma, devido à ação de oligarquias nas decisões que envolviam o currículo e a utilização de verbas nos seus sistemas escolares. Nesse sentido, o federalismo colaborativo previsto na $\mathrm{CF} / 1988$, que reconhecia os municípios como entes federais, sempre se constituiu como algo complexo para se implementar (DOURADO, 2013).

Moehlech (2012) pondera que, nos anos de 1990, termos como autonomia e descentralização passaram a fazer parte das discussões educacionais, balizadas por questões pautadas por organismos internacionais (Banco Mundial, Banco de desenvolvimento Interamericano e Fundo Monetário Educacional). Esses termos foram ressignificados e vistos como demandas de uma reorganização da lógica neoliberal que pautava a reordenação política e econômica no mundo. Nessa lógica, as responsabilidades dos sistemas escolares deveriam ser descentralizadas de forma a atribuir maior autonomia às escolas. Segundo Bonamino (2003), o processo de municipalização do ensino foi acelerado por meio da Emenda Constitucional 14/96, que criou o Fundo Nacional de Desenvolvimento do Ensino Fundamental e de Valorização do Magistério (FUNDEF) e instituiu um novo mecanismo de distribuição de recursos financeiros, que levava em conta o número de alunos matriculados nas redes públicas de ensino fundamental.

A municipalização do ensino passou a ficar mais enfática com a aprovação do Plano Nacional de Educação, que reforçava serem de responsabilidade dos municípios a oferta e a garantia da educação infantil e do ensino fundamental (CURY, 2010; XAVIER, 2003). No entanto, a municipalização foi insuficiente para promover a descentralização de fato, já que o Plano Nacional de Educação atribuiu à União o direito de baixar medidas legais para 
eventuais deficiências ou distorções, o que acabou por centralizar ações e fortalecer a instituição de um federalismo dependente e predatório.

Em 2006, o financiamento da educação passou abranger também o ensino médio por meio da aprovação da Emenda Constitucional 53/06 que criou o Fundo Nacional de Manutenção e Desenvolvimento da Educação Básica e de Valorização dos Profissionais da Educação (FUNDEB). Naquela conjuntura, nota-se que novas tentativas de operacionalizar a colaboração foram lançadas por ocasião, em 2007, do Plano de Desenvolvimento da Educação (PDE) que tinha como instrumento jurídico o Plano de Ações Articuladas (PAR), por meio do Decreto n. ${ }^{\circ}$ 6.094/07 (SOUZA; CASTRO, 2017). Com a reformulação do Plano Nacional de Educação (PNE) para o período 2014-2024, as relações de colaboração com repartição de responsabilidades e recursos tornaram-se mais evidentes, o que já estava anunciado pela Resolução CD/FNDE n 14/12 que criou o Fundo Nacional de Desenvolvimento da Educação (FNDE) e o Plano Dinheiro Direto na Escola (PDDE) ao estipular medidas para descentralização do financiamento (BONAMINO, 2003).

Nesse contexto, torna-se contundente a posição de Cury (2010) ao defender que, nas normas constitucionais e infraconstitucionais e nos objetivos de cada governo nas diferentes esferas administrativas, para garantir o direito a educação, evidenciam-se marcas de colaboração, o que permite ao autor afirmar que o federalismo no Brasil toma por base um sistema federativo por colaboração. A diversidade dessas marcas tem contribuído para a imprecisão do conceito de colaboração que acabou por produzir diferentes formas de compreensão e de expressão em mecanismos de colocar em prática a cooperação (ABRUCIO, SEGATTO E PEREIRA, 2017).

Com base nessas reflexões, passou-se a questionar: como vem sendo concebido o regime de colaboração em programas criados para colocá-lo em prática? Formas de se conceber o regime de colaboração fundamentadas no ordenamento jurídico educacional contribuem para a constituição de mecanismos de implementação da gestão democrática e de fortalecimento da autonomia pedagógica da escola? Podem incentivar a promoção da participação de diferentes segmentos da educação na formulação de políticas voltadas para a melhoria da educação? Qual o lugar da participação da sociedade civil em programas criados para operacionalizar regimes de colaboração? Tem lugar nessas formas de se conceber o regime de colaboração a promoção de inovações pedagógicas nas escolas?

Essas indagações foram motivadoras para se analisar a experiência implementada, nos anos de 2017 e 2018, no Espírito Santo, para adotar a colaboração entre o estado e os municípios com vistas a melhoria da aprendizagem na alfabetização. Para isso, realizou-se uma pesquisa documental que teve como corpus analítico diferentes fontes documentais como: Lei 10.787 de dezembro de 2017 (ESPÍRITO SANTO, 2017c), Lei 10.631 de março de 2017 (ESPÍRITO SANTO, 2017b), Projeto básico para Execução do Pacto pela Aprendizagem do Espírito Santo - Paes (ESPÍRITO SANTO, 2017d), Diretrizes para a Alfabetização (ESPÍRITO SANTO, 2017a), informações sobre o Programa Paes divulgadas no site da Sedu, materiais utilizados para a formação de professores e materiais didáticos enviados 
às escolas públicas para serem utilizados na alfabetização como ação no âmbito do referido programa.

A análise do corpus de documentos foi orientada pela perspectiva dialógica e, teoricamente, se embasou nos conceitos de enunciado, texto, dialogia formulados pelo círculo de Bakhtin (2003; 2004). Desse modo, tomou-se cada documento e suporte de divulgação de informações sobre o Paes como portadores de textos e discursos e, portanto, reveladores de concepções acerca da relação de colaboração, de gestão democrática, de formação de professores, de alfabetização e de autonomia. Partir dessas premissas, requereu considerar que os documentos materializam vozes, permitindo a identificação de posicionamentos e, portanto, de diferenças entre sujeitos que ocupam lugares e posições historicamente situados e datados. Assim, o diálogo com os documentos buscou, ao mesmo tempo, se aproximar deles para compreender posições e, também, para refletir sobre elas com a mediação de outras vozes de outros sujeitos.

Para apresentar os resultados das reflexões efetivadas, este artigo foi organizado em três partes, além das considerações iniciais e finais. Na primeira parte, resgatam-se diferentes vozes que discutem a temática regime de colaboração a partir de enfoques variados. Na sequência, retoma-se reflexões sobre a gestão democrática e a autonomia pedagógica. Na terceira parte, apresentamos o Programa pela Aprendizagem no Espírito Santo (Paes) e a análise de seus desdobramentos, destacando as limitações do programa como modelo de regime de colaboração para uma política de educação que promova a participação efetiva e a gestão democrática. Por fim, tecemos as considerações finais.

\section{Regime de colaboração}

A atuação partilhada entre união, estados e municípios nas competências afetas as políticas educacionais brasileiras foi se constituindo de diversas formas ao longo da história. No entanto, foi a CF/1988 que possibilitou o estabelecimento de norma comum para as relações intergovernamentais voltadas para a divisão de responsabilidades comuns que prenunciavam o que se denomina por regime de colaboração/cooperação (CASSINI, 2010).

Nesse sentido, os enunciados materializados na CF/1988 têm muito a nos indicar. Em seu artigo $1^{\circ}$ assegura que o Brasil é um país de regime republicano e sua forma de organização é a federativa, de cunho tridimensional, formada pela "[...] união indissolúvel dos Estados e Municípios e do Distrito Federal". A partir dos estudos de Araújo (2010) sobre o arranjo federativo brasileiro, é possível compreender que, além da relação de interdependência entre os entes federados, o federalismo tem como fundamento uma composição responsabilidades governamentais, ao mesmo tempo em que esteja assegurada a integridade do Estado nacional frente às inúmeras disputas e desigualdades regionais (ARAÚJO, 2010, p. 232). 
Ao instituir o municipalismo, concedendo aos municípios brasileiros a condição de ente federado autônomo, os Constituintes de 1988 intentaram tornar menos difícil à organização de coletividades territoriais, políticas e econômicas desiguais com a adoção do federalismo cooperativo. Araújo, Rodrigues e Cassini (2018), ao se referirem ao entrelaçamento entre os diferentes níveis de governo, destacam dois tipos de relações intergovernamentais: a competitiva e a cooperativa. A primeira corresponde ao federalismo dual que tem como alicerce a competição entre os entes federados, como nos Estados Unidos. Já o federalismo cooperativo entrelaça os níveis de governo os dotando de "[...] competências horizontais que os vinculam a atuar em conjunto, a fim de atingirem objetivos comuns (ARAÚJO, 2018, p. 27)", como na Alemanha. Araújo (2010) nos alerta para o fato de que, apesar de a Carta Magna adotar o federalismo cooperativo,

[...] o pacto federativo brasileiro se aproxima do modelo alemão, mas preserva as técnicas de repartição de competências típicas do federalismo norte-americano, em que se estabelecem competências fixas e reduzidas à União, sendo o restante das competências distribuídas às unidades subnacionais (ARAÚJO, 2010, p. 234).

Cabe ressaltar que, no federalismo cooperativo, o Estado deve atuar tanto no sentido de coordenação federativa como no de cooperação, a fim de assegurar uma integração entre as políticas e a equalização das condições sociais de vida em todos os 26 estados, no Distrito Federal e os 5.570 municípios brasileiros, especificamente, o direito à educação. Nesse contexto, torna-se necessário clarificar a distinção entre coordenação e colaboração federativa, tendo em vista que

[...] a primeira se constitui em procedimento que busca resultado comum a partir do governo central, apesar da autonomia dos entes federados" e a segunda "[...] se traduz no modo de atribuições e exercício das competências concorrentes e comuns, devendo a tomada de decisões e o exercício das competências serem conjuntas e não isoladas (ARAUJO, 2010, p. 238).

Em consonância com a organização federativa prescrita no artigo 23 da Constituição Federal que estabelece as competências da União, dos estados, do Distrito Federal e dos municípios, o artigo 211 define responsabilidades compartilhadas, previstas no regime de colaboração. Ainda no texto Direito à educação básica: a cooperação entre os entes federados, Araújo (2010) nos chama a atenção para o fato de que a CF/1988 foi "imprecisa" no que se refere ao regime de colaboração, uma vez que faz uso das terminologias como "normas de cooperação" (§ único do artigo 23), "regime de colaboração" (artigo 211) e "formas de cooperação" ( $\S 4^{\circ}$ do artigo 211) para se referir ao regime de colaboração/ cooperação entre as três esferas da administração, na execução e na organização dos serviços públicos. Para além da questão conceitual, materializada nos enunciados da Carta Magna, a autora ressalta que o regime de colaboração é um "[...] instrumento necessário à 
gestão associada da competência material comum, inserida nos aspectos jurídico-políticos da Constituição (não fiscal)" (ARAÚJO, 2010, p. 238).

Diferentes autores (ARAUJO, 2010; 2013; COSTA, 2010; FERNANDES, 2013; SENA, 2018; NASCIMENTO; ALVES; FERRARI, 2018) têm pontuado que não há uma lei de âmbito federal que especifique de que maneira o regime de colaboração deve ser estabelecido com as atribuições e as formas de articulação dos entes federados. E esta lacuna "[...] facilita a abertura de brechas para que omissões aconteçam, além da utilização com frequência, por parte da União, da coordenação federativa, em que os demais entes federados são induzidos a aderirem às políticas federais elaboradas" (FERNANDES, 2013, p. 172).

A título de exemplo da indução de políticas por meio de financiamento de fundos, programas e ações priorizadas pela esfera federal, como explicitado anteriormente, cita-se o FUNDEF e, posteriormente, o FUNDEB, que instituiu mecanismos de redistribuição de receitas, numa ação de coordenação do financiamento da educação e não de colaboração. Outros exemplos são o PDDE, uma política pública de repasse de verbas do FNDE diretamente para as escolas, os testes em larga escala, as definições curriculares, o PDE e o PAR, que são "[...] ações de coordenação da União, com a indução de políticas para a área da educação traduzidas, erroneamente, como colaboração" (ARAÚJO, 2010, p. 239). Conforme salienta a autora,

[...] em que pese a relevância de algumas medidas de coordenação federativa, necessárias, são insuficientes para garantir a igualdade quanto ao direito à educação na desigual federação brasileira. $O$ debate e a normatização de competências e recursos têm sido geralmente tratados de maneira pontual, fragmentada e imediata, sem uma análise sobre os conflitos federativos, que estão na sua base jurídico-política e material (ARAÚJO, 2010, p. 240).

Outra questão que dificulta o estabelecimento das normas do regime de colaboração, é a não definição de um Sistema Nacional de Educação como foi feito com o Sistema Único de Saúde (SUS), o Sistema Nacional de Emprego (Sine) e o Sistema Financeiro Nacional (SFN). Já na $1^{a}$ edição do livro Educação brasileira: estrutura e sistema, em 1975, Saviani pontuava a necessidade de um Sistema Nacional e Articulado de Educação, como "[...] um conjunto dinâmico, com seus elementos interagindo, incorporando contradições e comportando-se, ao mesmo tempo, como condicionado e condicionante do contexto em que está inserido" (SAVIANI, 2008, p. 32).

Em 1996, com a aprovação da Lei de Diretrizes e Bases da Educação Nacional (Lei n 9.394/96), o regime de colaboração passou a assumir maior evidência e definição a partir dos artigos 5, 8, 9, 10,11, 62 e 74, pois foram definidas competências para a União, para os estados e para os municípios, bem como foram estabelecidos os contextos em que a colaboração deveria se efetivar. Vale pontuar que até a aprovação da referida Lei, tínhamos no país apenas duas modalidades de sistemas de ensino: o federal, que abarcava as escolas superiores (públicas e particulares) que estavam subordinadas às normas estabelecidas 
pela União; e os sistemas estaduais e do Distrito Federal, que abrangiam as escolas de educação básica (públicas e particulares).

Com a Lei $n^{\circ}$ 9.394/1996, foi estabelecida a existência dos sistemas municipais de ensino e atribuída como responsabilidade dos municípios (artigo 11) a organização do sistema municipal de ensino, a ação redistributiva em relação as suas escolas, a autorização, o credenciamento e a supervisão de instituições de ensino do seu sistema, a elaboração de normas complementares para seu sistema, bem como o transporte escolar dos alunos dos sistemas municipais.

Aos estados (artigo 10) coube a organização do sistema estadual de ensino, a autorização, o reconhecimento, o credenciamento, a supervisão e a avaliação de cursos superiores e instituições de ensino do seu sistema, bem como o transporte escolar dos alunos dos sistemas estaduais. À União (artigo 9) foi conferida a assistência técnica e financeira aos estados, Distrito Federal e municípios, assim como a autorização, o reconhecimento, o credenciamento, a supervisão e a avaliação de cursos superiores e instituições de ensino do sistema federal, além do estabelecimento de normas gerais para os cursos de graduação e pós-graduação.

Não obstante, Costa (2010) esclarece que a própria Lei no 9.394/1996 pouco avançou na constituição de um Sistema Nacional e Articulado de Educação, orgânico na sua diversidade, ao instituir sistemas federal, estaduais e municipais de ensino. É nessa linha de preocupação que Araújo (2010) considera que o grande desafio para a constituição de um efetivo regime de colaboração, que organize um Sistema Nacional e Articulado de Educação é

[...] o debate denso e consistente sobre as relações intergovernamentais no Brasil quanto à oferta educacional, o que pressupõe o estabelecimento de uma justa distribuição de poder, autoridade e recursos entre os entes federados, garantindo a interdependência e interpenetração dos governos nacional e subnacionais, sem que haja comprometimento de um projeto de desenvolvimento nacional, do qual um dos elementos é a educação (ARAÚJO, 2010, p. 240).

Cassini (2010), em seu trabalho intitulado Federação e educação no Brasil: a atuação do poder legislativo nacional para regulamentação do regime de colaboração, identifica o estado do Espírito Santo como um dos poucos da federação que regulamenta o regime de colaboração por meio de leis estaduais. Um exemplo, é a Lei n ${ }^{0} 10.631$, de 28 de março de 2017, que institui o Pacto pela Alfabetização no Espírito Santo (Paes), objeto das reflexões deste artigo.

No site da Secretaria de Estado da Educação (https://sedu.es.gov.br/Not\%C3\%ADcia/sedu-alinha-acoes-pedagogicas-para-municipios adeptos-ao-pacto-pela-aprendizagem-no-es), o Paes é anunciado como uma iniciativa do Governo do Estado, "[...] desenvolvida a partir do estabelecimento de um regime de colaboração entre o Estado e as redes municipais de ensino" (Acesso em $10 \mathrm{dez}$ 2017). 
Nesse sentido, torna-se importante refletir sobre o alcance de Programas, como o Paes, instituído por Lei Estadual, no que diz respeito ao cumprimento dos preceitos constitucionais afetos aos princípios da gestão democrática e da autonomia pedagógica de secretarias municipais de educação e de escolas. Vale lembrar que o federalismo, segundo a representação da Unesco no Brasil, deve contribuir para a consolidação da democracia e para aumentar a participação dos sujeitos nas ações políticas. Portanto, a análise do Paes possibilita tematizar uma concepção de regime de colaboração e vinculações desse regime com a promoção da gestão democrática e o fortalecimento da autonomia pedagógica. Vale destacar que a gestão democrática e autonomia pedagógica são previstas na legislação em vigor, e já foi abordada por vários estudiosos do campo da educação.

\section{Gestão democrática e autonomia pedagógica}

Nos limites das indagações que se colocam como objeto deste artigo, parte-se do pressuposto de que a gestão democrática é um mecanismo garantidor da autonomia pedagógica da escola. Ela se sustenta na participação dos diversos sujeitos que constituem a comunidade escolar, tendo a prática do diálogo como meio para a efetivação da autonomia pedagógica da escola (SANDER, 2005).

Tal pressuposto encontra respaldo tanto na CF/1988 como na Lei $n^{\circ}$ 9.394/1996, que facultam a comunidade escolar o direito de exercerem o controle sobre os serviços oportunizados pelo poder público e ainda de participarem da gestão pedagógica das instituições escolares. No entanto, apesar da legislação garantir esse direito, a prática da gestão democrática não é algo tão comum nas diferentes instâncias responsáveis pela educação. É uma prática desafiadora que necessita ser aprimorada por meio da promoção efetiva do diálogo entre os diferentes sujeitos que constituem essas instâncias, bem como nos processos que envolvam a tomada de decisões sobre os rumos da educação (SANDER, 2005).

A Lei $n^{\circ}$ 9.394/1996, para Sander (2005), é sem dúvida uma das manifestações da luta em busca da construção democrática, considerando-se que, na referida Lei, foi incorporado o princípio da gestão democrática expresso no artigo 206 da CF/1988. Sobre esse aspecto, o autor pondera que

[...] as leis de ensino asseguram a autonomia da escola pública, a participação dos educadores na elaboração do projeto pedagógico da escola e a participação da comunidade escolar e da comunidade local em conselhos escolares (SANDER, 2005, p. 50).

Para além da participação da comunidade escolar, Gadotti (2014) mostra que a gestão democrática é um princípio pedagógico e também um preceito constitucional, ao chamar atenção para o fato de que o 
[...] parágrafo único do artigo primeiro da Constituição Federal de 1988 estabelece como cláusula pétrea que "todo o poder emana do povo, que o exerce por meio de representantes eleitos ou diretamente", consagrando uma nova ordem jurídica e política no país com base em dois pilares: a democracia representativa (indireta) e a democracia participativa (direta), entendendo a participação social e popular como princípio inerente à democracia (GADOTTI, 2014, p. 01).

Mesmo que a CF/1988, em seu artigo 206, tenha estabelecido os "princípios do ensino", e incluído como um deles, no Inciso VI, a "gestão democrática do ensino público" e que esse tenha sido retomado na Lei n 9.394/1996, Gadotti (2014) alerta que a gestão democrática ficou reduzida, no texto da Lei n 9.394/1996, à participação dos profissionais, no projeto pedagógico, e da comunidade, nos conselhos escolares, e instituiu apenas a progressiva autonomia pedagógica, administrativa e de gestão financeira das unidades escolares. Sendo assim, vale retomar o artigo 205 da CF/1988, no que diz respeito a colaboração da sociedade para a promoção e incentivo da educação, que define:

[...] educação, direito de todos e dever do Estado e da família, será promovida e incentivada com a colaboração da sociedade, visando ao pleno desenvolvimento da pessoa, seu preparo para o exercício da cidadania e sua qualificação para o trabalho (BRASIL, 1988).

Portanto, por esse artigo, a gestão democrática na administração da educação, exige, de diferentes sujeitos responsáveis pelas políticas, atitudes democráticas, e, ainda, dos gestores, independente das instâncias de atuação, posturas que promovam a participação e o envolvimento de todos os segmentos nas discussões e definições das políticas educacionais, o que demanda compreender a educação e o ensino como objetos de interesse públicos. Assim, para o envolvimento participativo de todos os segmentos se faz necessário desenvolver sentimentos de pertencimento com os projetos educacionais implementados, o que se coloca como ação central de uma administração democrática.

A administração democrática pode ser relacionada ao que Lima (2002) denomina por governança democrática, e que possui sintonia com princípios freirianos. Para Freire (1994), o exercício da democracia possibilita a aprendizagem da democracia, o que prevê participação de alta intensidade. Lima (2002) sinaliza que o exercício e a aprendizagem da democracia favorecem o processo de conscientização a superação da consciência ingênua para o exercício da consciência crítica.

É seguindo essa perspectiva que se acredita, como Gadotti (2014), que a gestão democrática está assentada numa concepção de educação, tornando-se, desse modo, impossível conceber educação democrática no contexto de políticas educacionais tecnocráticas ou autoritárias. A gestão democrática pressupõe uma concepção de educação democrática e emancipadora. Como bem salientou Paulo Freire (1981, 1994, 1996 e 2001), é fundamental para a garantia da democracia uma educação emancipadora, dialógica, participativa e, por isso, democrática. 
Nessa perspectiva, o pensamento de Freire (1981, 1994, 1996 e 2001) se coaduna com as reflexões de Sander (2005) e de Gadotti (2014), no que diz respeito a concepção de democracia como um processo. Para os três autores, a democracia é uma conquista da sociedade civil organizada, que se efetiva por meio de lutas para a construção de uma sociedade pautada em práticas que valorizem a participação coletiva, o respeito mútuo e, principalmente, o diálogo.

Para Freire (2001), compreender a democracia como processo demanda reconhecê-la como constitutiva do que ele denomina por processo de humanização do ser humano. Segundo Freire (2001), o homem é "[...] um ser finito, limitado, inconcluso, mas consciente de sua inconclusão. Por isso, um ser ininterruptamente em busca, naturalmente em processo" (Freire, 2001, p.18). Nesse sentido, entendendo a democracia como conquista e como resultado de lutas em defesa dos interesses coletivos, o que inclui interesses dos que são excluídos de tomadas de decisões, é possível afirmar que ela só pode se constituir por meio do diálogo.

Nas reflexões de Paulo Freire é notória a defesa de uma ação libertadora da opressão social, por meio de práticas dialógicas, uma vez que, para Freire (1981), é impossível falar em democracia, mas, ao mesmo tempo, criar mecanismos para silenciar o povo. Para o autor, isso se constitui no que chama de farsa. Assim como, para ele, não é possível falar em humanização e negar os homens, pois, assim, tudo se torna uma mentira. Portanto, o conceito de humanização torna-se, a partir de Freire (1981), fundamental para a compreensão de mecanismos que contribuem para a gestão democrática.

Importante esclarecer que humanizar é, para Freire (1981), tarefa de todo ser humano, o que pressupõe um processo de constituição do indivíduo como um sujeito autônomo, consciente, sujeito da história. No entanto, é preciso ter claro também que o processo de libertação não é individual, é coletivo, pois os homens não se libertam sozinhos, mas sim em comunhão com os outros. Sobre o processo de libertação, o patrono da educação brasileira diz:

A libertação, por isto, é um parto. É um parto doloroso. O homem que nasce deste parto é um homem novo que só é viável na e pela superação da contradição opressores-oprimidos, que é a libertação de todos. A superação da contradição é o parto que traz ao mundo este homem novo, não mais opressor; não mais oprimido, mas homem libertando-se (FREIRE, 1981, p.36).

Nessa perspectiva de compreensão do processo de libertação como processo de humanização, o diálogo assume centralidade como categoria conceitual para reflexões sobre a democracia e, consequentemente, sobre a gestão democrática. Vale ressaltar que, segundo Freire (1981), o diálogo assegura ao ser humano o direito dele apresentar ao mundo suas crenças, suas convicções, sua forma de pensar, ou seja, confere ao sujeito a possibilidade dele transformar o mundo e a si mesmo. Portanto, o diálogo possibilita a humanização, uma vez que estabelece entre os indivíduos compromissos e abre a consti- 
tuição de redes de confianças e de pertencimentos. Freire (1981, p. 96) destaca que "[...] ao fundar-se no amor, na humildade, na fé nos homens, o diálogo se faz numa relação horizontal, em que a confiança de um pólo no outro é consequência óbvia [...]".

Assim, o pensamento de Freire anuncia-se como uma práxis fundamentada numa ética pedagógica-política e epistemológica essencialmente democrática em que é possível compreender a democracia como respeito as individualidades e singularidades humanas, $\mathrm{o}$ que fica evidenciado no seguinte trecho:

O respeito à autonomia e a dignidade de cada um é um imperativo ético e não um favor que podemos ou não conceder uns aos outros. [...] É nesse sentido também que a dialogicidade verdadeira, em que os sujeitos dialógicos aprendem e crescem na diferença, sobretudo, no respeito a ela, é a forma de estar sendo coerentemente exigida por seres que, inacabados, assumindo-se como tais, se tornam radicalmente éticos (FREIRE, 1996, pp. 66-67).

As considerações de Freire (1981, 1994, 1996 e 2001), de Sander (2005) e Gadotti (2014) oportunizam pensar em que medida práticas políticas que buscam implementar regime de colaboração consideram princípios legais como o da gestão democrática e da autonomia pedagógica em seus programas voltados para a melhoria da educação básica e para a formação da cidadania e o fortalecimento do espaço público democrático.

Vale lembrar que a descentralização que se coloca como forma de organização política e administrativa no federalismo participativo, previsto na legislação brasileira, impulsiona formas de implementação de regimes de colaboração, seja, como pontuado por Abrucio (2010), pela garantia de recursos a estados e municípios, seja pela gestão de políticas sociais implementadas pelos governos subnacionais, seja, ainda, pelo status de ente federado conferida aos municípios. Nesse contexto, é oportuno lembrar, como destacado por Duarte (2004), que a educação é um direito social, previsto no artigo $6^{\circ}$ da CF/1988, público subjetivo, o que faculta aos indivíduos possibilidade de fazer uso do ordenamento jurídico (direito objetivo) para contemplar seus direitos (direito subjetivo). Para garantia do exercício desse direito, a escola se coloca como uma das formas mais efetivas.

Nesse sentido, torna-se importante refletir sobre formas de colaboração que contemplem intervenções sobre a gestão administrativa e pedagógica de redes e sistemas de ensino e das unidades escolares que as integram, considerando-se o impacto delas no que se refere aos preceitos legais da gestão democrática e da autonomia pedagógicas, bem como para a formação dos profissionais que atuam na educação em diferentes instâncias. É o que este artigo apresenta a seguir a partir da análise do Programa denominado Pacto Aprendizagem no Espírito Santo (Paes). 


\section{O regime de colaboração implementado pelo Programa Paes}

O Programa Paes foi instituído no Espírito Santo, pela Lei Estadual n 10.631/2017, com o objetivo de viabilizar e fomentar o regime de colaboração entre Estado e Municípios. A colaboração é definida no artigo $1^{\circ}$ da Lei que dispõe que ela se efetivará a

[...] a partir do diálogo permanente e ações conjuntas voltadas ao fortalecimento da aprendizagem e à melhoria dos indicadores educacionais dos alunos, das unidades de ensino e das referidas redes da educação básica no Espírito Santo [...] (ESPÍRITO SANTO, 2017b).

Desse modo, o programa criado pelo Governo do Estado do Espírito Santo opera uma forma de colaboração vertical para solucionar problemas de aprendizagem e de gestão da educação tanto em nível estadual como municipal. Há de se levar em conta que, no federalismo brasileiro, a CF/1988 confere, pelo artigo 18, autonomia aos entes federados, porém com determinado grau de liberdade no que tange a organização, a administração e ao governo, uma vez que outros artigos definem obediências a estados e municípios.

Nesse contexto, há que se considerar ainda que o próprio parágrafo único do artigo 23 da CF/1988, ao definir que "lei complementar fixará normas para a cooperação entre a União, Estados e Municípios, tendo em vista o equilíbrio do desenvolvimento e do bem estar em âmbito nacional", indica que há necessidades de se definir limites para a colaboração, considerando não se ter uma definição explicita desse regime, como já apontado por Cury (2010), Araújo (2010) e Abrucio (2002). Dessa forma, diante da ausência de definições precisas acerca de normas para implementar a colaboração, entende-se que programas instituídos para operar regimes de colaboração podem impor subordinações e determinações unilaterais que contribuam para a desconsideração da autonomia, principalmente os que se caracterizam como colaboração vertical, o que pode ser comprovado com o Paes que implementa uma forma gerencialista e centralizadora de regime de colaboração voltada para induzir e regular os municípios na implementação de ações previamente organizadas pelo Estado.

Isso fica evidente no Paes que, apesar de propagar, nos seus princípios norteadores, que o programa se desenvolverá com "espírito de colaboração entre Estado e Municípios e não de subordinação" e, ainda, com "flexibilidade para ajustes às especificidades de cada região/município" (ESPÍRITO SANTO, 2017, p. 8), demonstra desconsiderar as especificidades locais e regionais e a autonomia desses, uma vez que adota também o princípio de que "[...] alunos são do território do Espírito Santo e não de redes de ensino (ESPÍRITO SANTO, 2017, p. 8)" e fixa uma estrutura de assessoramento em nível central na Sedu e regional nas Superintendências Regionais de Educação para a implementação das ações do programa.

É importante chamar atenção para o fato de que discursivamente a Lei apregoa a valorização de práticas que fomentam a participação e o diálogo entre estado e municípios, 
porém, com enfoque para a melhoria de indicadores, demostrando, com isso, que o foco central do programa é o resultado e não o processo educacional. Com a lógica da melhoria de indicadores, o Paes demarca sua aderência a política de avaliação externa, induzida por organismos internacionais, principalmente a partir dos anos 1990, como meio de produzir métricas que referenciem a qualidade da educação (BONAMINO; SOUZA, 2012). Métricas definidas externamente às escolas, desconsiderando as condições objetivas e os contextos singulares e particulares nos quais as instituições se inserem.

Segundo Costa, Vidal e Vieira (2019) a avaliação da educação, com a profusão de informações estatísticas, se constituiu como forma de regulação, principalmente os processos de avaliação externa em larga escala, que institucionalizam formas de colaboração, em que o governo estadual assume a forma de coordenador federativo e, ancorando-se no fundamento de que a descentralização e a autonomia são características do federalismo brasileiro, instituem sistemas estaduais de avaliação. A literatura da área educacional, aponta que a centralização de processos avaliativos favorece a imposição de normas e metodologias para se chegar a resultados. Nesse sentido, a centralização da avaliação promove um desdobramento da ação pedagógica como processo e dos resultados como produto (COSTA; VIDAL; VIEIRA, 2019).

No Paes é evidente o peso conferido a política de avaliação externa, incluindo a diagnóstica, centralizada na Secretaria Estadual de Educação, como indicam as informações do Ofício 04/2018 da Coordenação do Pacto pela Aprendizagem no Espírito Santo (Copaes), o qual demonstra que a Sedu se coloca como coordenadora central da avaliação, definindo, inclusive, com cronogramas, procedimentos para os municípios realizarem a avaliação de suas escolas, formas de controle para acesso aos resultados e intervenções via formação continuada. Assim, o Estado, por meio do Paes, promove uma centralização da avaliação diagnóstica que induz os municípios a aderirem a lógica proposta pela Sedu. Com esse mecanismo, o Paes contribui para criar a obrigatoriedade da participação dos municípios à política de avaliação coordenada pelo Estado. 
Figura 1- Cronograma da avaliação diagnóstica do Paes

\begin{tabular}{|c|c|c|}
\hline \multicolumn{3}{|c|}{ CRONOGRAMA - Avaliação Diagnóstica (10 Ano EF) - PAES } \\
\hline DATA & AÇÃO & RESPONSÁVEIS \\
\hline $26 / 01$ & Reunião inicial - Alinhamento com as SREs' & $\begin{array}{c}\text { COPAES (Líder do Fortalecimento da } \\
\text { Aprendizagem) }\end{array}$ \\
\hline $29 / 01$ a $02 / 02$ & $\begin{array}{l}\text { I REUNIÃO DOS NUPAES (orientações gerais para as } \\
\text { secretarias municipais) }\end{array}$ & Lideranças regionais (SRE's) \\
\hline $05 / 02$ a $09 / 02$ & Orientação aos profissionais da rede estatual & Lideranças regionais (SRE's) \\
\hline $05 / 02$ a $16 / 2$ & Orientação aos profissionais das redes municipais & Técnicos Municipais \\
\hline $19 / 02$ a $02 / 03$ & SEMANA DA AVALIAÇÃO & Pedagogos e professores \\
\hline $05 / 03$ a 13/03 & $\begin{array}{l}\text { Inserção dos resultados da avaliação no Google } \\
\text { Forms }\end{array}$ & Escolas \\
\hline 05/03 a 13/03 & $\begin{array}{l}\text { Monitorar a inserção dos dados das escolas } \\
\text { municipais }\end{array}$ & Técnicos municipais \\
\hline $05 / 03$ a $13 / 03$ & $\begin{array}{l}\text { Monitorar a inserção dos dados das escolas estaduais } \\
\text { e das redes municipais dos municípios jurisdicionados }\end{array}$ & Lideranças regionais (SRE's) \\
\hline $14 / 03$ a $22 / 03$ & $\begin{array}{l}\text { Analisar o resultado das avaliações e propor } \\
\text { estratégias de intervenções via Formação Continuada }\end{array}$ & COPAES \\
\hline $27 / 03$ & Reunião de devolutivas para as Lideranças Regionais & COPAES \\
\hline $29 / 03$ & Reunião de devolutivas para os Técnicos Municipais & Lideranças regionais (SRE'S) \\
\hline
\end{tabular}

Fonte: acervo dos pesquisadores

No documento Projeto Básico para implementação do Programa, a melhoria dos indicadores está focada em duas frentes de atuação que são apresentadas como dois desafios a serem vencidos no Espírito Santo, inclusive para justificar a importância do Paes: a expansão da oferta de vagas para crianças de 0 a 3 anos e a melhoria da qualidade da educação e de sua atratividade para crianças e jovens de 15 a 17 anos. O primeiro desafio é associado à expansão dos investimentos em infraestrutura para garantir a ampliação do acesso. O segundo à melhoria da qualidade do ensino. O que é utilizado como pressuposto para a melhoria da qualidade de ensino é a colaboração que deve estar presente em todas as discussões que envolvem a oferta/qualidade da educação básica (ESPÍRITO SANTO, 2017d, p.6) e, em especial, no ensino fundamental.

É interessante notar que o referido documento cita também a Lei $n^{\circ} 10.382 / 2015$ que criou o Plano Estadual de Educação do Espírito Santo com período de vigência 20152025, dando destaque para as metas previstas para a educação infantil e para o ensino fundamental, referenciadas para justificar a necessidade do Programa e a sua abrangência ao ensino fundamental, anos iniciais e finais, da rede pública estadual e municipal, assim como à educação infantil.

A melhoria de indicadores da educação infantil e do ensino fundamental é projetada no Projeto Básico na parceria entre a Sedu e as Prefeituras Municipais com ações focadas nas salas de aula e voltadas para resultados de aprendizagem (ESPÍRITO SANTO, 2017d p.07). Desse modo, torna-se evidente que o Paes constitui uma forma de colaboração com 
os municípios que busca a melhoria dos indicadores por meio de intervenções sobre a prática de ensino. Isso fica comprovado com a informação divulgada, no site da Sedu, de que a estratégia para a melhoria de indicadores se daria por utilização de material pedagógico, formação continuada, organização curricular e avaliação seguindo um único padrão para o estado e municípios. Nota-se, assim, que a colaboração proposta pelo Paes privilegia a lógica da uniformização da prática docente, o que se comprova também no seguinte trecho divulgado no site da Sedu:

\begin{abstract}
A premissa do PAES é que exista apenas o aluno da rede capixaba, e não mais da rede estadual ou municipal de ensino. O objetivo é alcançar melhorias nos indicadores educacionais através de ações pedagógicas conjuntas, aproveitando estrutura única de fornecimento de material estruturado, formação continuada, currículo e avaliação (ESPÍRITO SANTO, 2017e).
\end{abstract}

Para intervir na prática do professor, o Paes propõe uma estrutura em três eixos de atuação. O eixo "Apoio à Gestão" compreende ações relacionadas ao desenvolvimento de habilidades voltadas ao fortalecimento da gestão em seus mais diversos níveis, ou seja, desde as secretarias municipais até a gestão do tempo e dos espaços pedagógicos em sala de aula. Abrange a construção, a compreensão, a disseminação e o monitoramento de indicadores e metas de qualidade da educação. O eixo "Fortalecimento da Aprendizagem" engloba o desenvolvimento de estratégias relacionadas diretamente ao fazer pedagógico nas unidades escolares. Define-se por estabelecer rotinas claras de formação, monitoramento, avaliação, além do apoio à disseminação de práticas pedagógicas exitosas. O eixo "Planejamento e Suporte" abrange ações relacionadas a estudos referentes à reorganização da oferta educacional nos municípios de maneira a garantir a otimização da alocação de recursos didáticos, humanos, financeiros e materiais. Compreende ainda análises referentes a demanda por vagas e necessidade de aparelhamento da rede de educação infantil, entre outros.

Em todos os eixos fica evidenciada a importância atribuída ao controle da prática docente com a previsão de ações de gestão do tempo e dos espaços da sala de aula, as estratégias de ensino com o estabelecimento de rotinas pedagógicas monitoradas. Portanto, o Paes se constitui num programa indutor e regulador de práticas docentes. Isso fica mais visível com os aspectos que são definidos para cada eixo: objetivos específicos, metas, metodologias e produtos pedagógicos a serem elaborados.

Todos os eixos contam com uma equipe técnica constituída por coordenação geral, especialistas, coordenações regionais, equipes municipais, incluindo coordenador municipal. O eixo "Fortalecimento da Aprendizagem" conta também com uma equipe de formadores municipais. Além desses aspectos, no organograma apresentado para ilustrar a composição de cada equipe por eixo, fica constatada a centralidade da Sedu sob os demais integrantes de cada equipe municipal, deixando evidenciado que o Paes, como uma política de regime de colaboração, alicerça-se sob um modelo de gestão gerencialista e centraliza- 
dora, o que é também verificado na definição das metodologias dos eixos que, conforme ilustra o Quadro 1, corroboram a centralidade na avaliação e demonstram regulação na formação de profissionais tanto de gestores como de professores para avaliar e implementar propostas didáticas que tenham como suporte material pedagógico estruturado. Pelas metodologias propostas para os eixos, o maior propósito do Paes é incidir sob a alfabetização, tomando como ponto de partida a avaliação diagnóstica.

Quadro 1: Demonstrativo de metodologias, por eixo, do Paes.

\begin{tabular}{|c|c|c|}
\hline Apoio à gestão & $\begin{array}{l}\text { Fortalecimento da Aprendiza- } \\
\text { gem }\end{array}$ & Planejamento e Suporte \\
\hline $\begin{array}{l}\text { Desenvolvimento de avalia- } \\
\text { ção diagnóstica }\end{array}$ & $\begin{array}{l}\text { Assessoria e apoio técnico para } \\
\text { implementação e implantação de } \\
\text { propostas didáticas de alfabeti- } \\
\text { zação }\end{array}$ & $\begin{array}{l}\text { Realização de estudo de } \\
\text { planejamento de rede fí- } \\
\text { sica escolar do Estado e } \\
\text { Municípios }\end{array}$ \\
\hline $\begin{array}{l}\text { Construção de indicadores } \\
\text { de eficiência de gestão e de } \\
\text { rede }\end{array}$ & $\begin{array}{l}\text { Assessoria e acompanhamento } \\
\text { das ações para implementação } \\
\text { de plano de formação continuada } \\
\text { dos professores alfabetizadores }\end{array}$ & $\begin{array}{l}\text { Investimento em infraes- } \\
\text { trutura voltada ao atendi- } \\
\text { mento da educação infan- } \\
\text { til }\end{array}$ \\
\hline $\begin{array}{l}\text { Assessoramento na compre- } \\
\text { ensão dos indicadores }\end{array}$ & $\begin{array}{l}\text { Realização de seminários e ofici- } \\
\text { nas }\end{array}$ & $\begin{array}{l}\text { Expansão da oferta da } \\
\text { educação em tempo inte- } \\
\text { gral }\end{array}$ \\
\hline $\begin{array}{l}\text { Construção de planejamento } \\
\text { e gestão/definição de metas } \\
\text { para as escolas e municípios } \\
\text { Supervisão/monitoramento } \\
\text { das atividades realizadas } \\
\text { Realização de encontros } \\
\text { Assessoramento na capta- } \\
\text { ção de recursos }\end{array}$ & $\begin{array}{l}\text { Assessoria e incentivo de partici- } \\
\text { pação das famílias } \\
\text { Coordenação de ações refe- } \\
\text { rentes a elaboração de material } \\
\text { técnico e didático pedagógico do } \\
\text { eixo de alfabetização } \\
\text { Elaboração de cadernos de ativi- } \\
\text { dades para o aluno e manuais } \\
\text { Materiais impressos e construí- } \\
\text { dos de forma didática para inser- } \\
\text { ção no portal do PAES } \\
\text { Realização de seminários regio- } \\
\text { nais } \\
\text { Elaboração de relatórios parciais } \\
\text { e finais } \\
\text { Realização de estudos e pesqui- } \\
\text { sas }\end{array}$ & $\begin{array}{l}\text { Racionalização de cus- } \\
\text { tos a partir de compar- } \\
\text { tilhamento de modelos } \\
\text { de transporte, sistema } \\
\text { de matrículas, softwares, } \\
\text { plataformas e outros }\end{array}$ \\
\hline
\end{tabular}

Fonte: Projeto Básico para Execução do Paes (2017).

Nota: Informações adaptadas pelos autores.

A lógica centralizadora e regulatória que constitui o Paes se reafirma no modelo de colaboração para a formação de professores, que se organiza a partir de materiais estruturados (Material do Professor, Material do aluno, Jogos, Livros de Literatura) adquiridos de programa desenvolvido no Ceará, revelando a desconsideração com os saberes e fazeres docentes locais. Os materiais estruturados enviados para todas as escolas, inclusive para as municipais 
que não haviam assinado o Paes, mantém articulação com os conhecimentos que fazem parte da matriz da avaliação diagnóstica e com a organização do currículo para a alfabetização.

Assim, nota-se a centralidade conferida pelo Paes para o estabelecimento de uma estrutura única orientadora da prática docente para todas as escolas. A avaliação diagnóstica da alfabetização, que é efetivada com material "passo a passo" a ser seguido pelo professor, confirma a intencionalidade com a uniformização de práticas docentes. Isso traduz também a vinculação do Programa com uma política de avaliação voltada exclusivamente para a produção de indicadores que permitam a comparação entre escolas, bem como classificações entre elas e redes e sistemas estadual e municipais.

A avaliação diagnóstica implementada pelo Paes demonstra estreita vinculação com a organização curricular voltada para o ensino inicial da leitura e da escrita, uma vez que os conhecimentos sobre o sistema de escrita da matriz da avaliação compõem os materiais didáticos enviados para as escolas e também as diretrizes curriculares, o que pode ser constatado no documento intitulado Diretrizes Curriculares 2017, que define os eixos curriculares para as disciplinas de Língua Portuguesa e Matemática para a alfabetização. Esses aspectos demonstram o caráter regulador do Paes, pois tanto a avaliação, como a organização curricular e os materiais estruturados para as escolas e formação de professores reafirmam a intervenção do estado nas formas de gestão da rotina de trabalho com as crianças em escolas.

Figura 3 -Página da prova

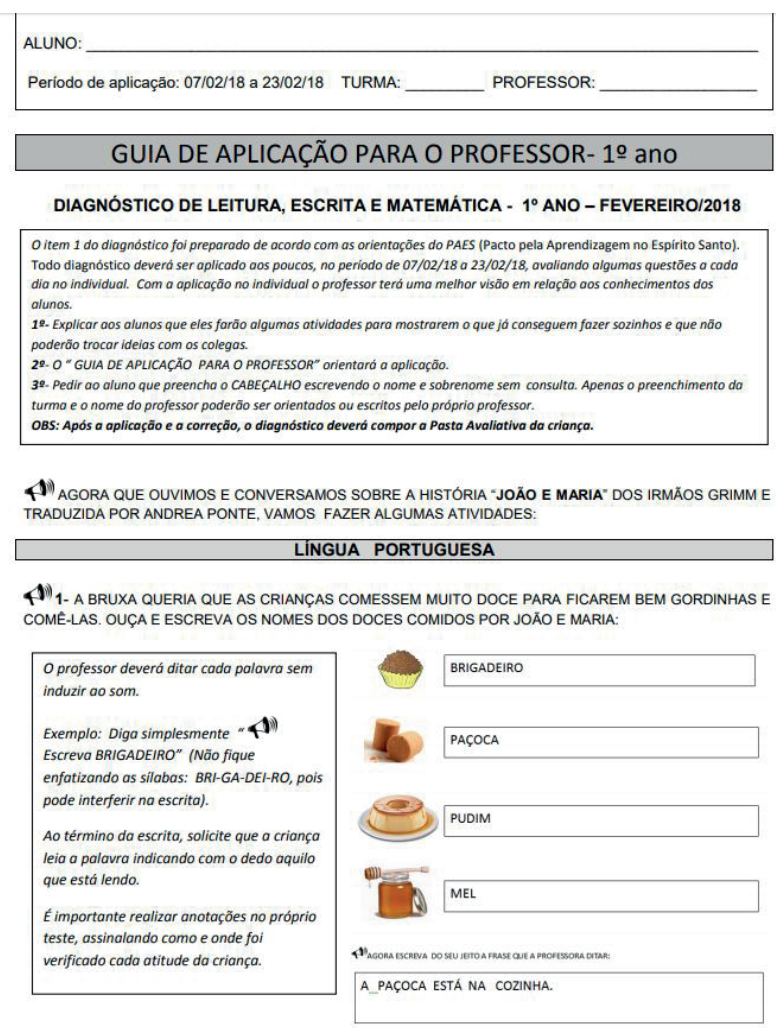

Fonte: Acervo dos pesquisadores (2017). 
Figura 4 -Capa do documento Diretrizes Curri- Figura 5 -Sumário do documento Diretrizes Curricula-

culares para Alfabetização

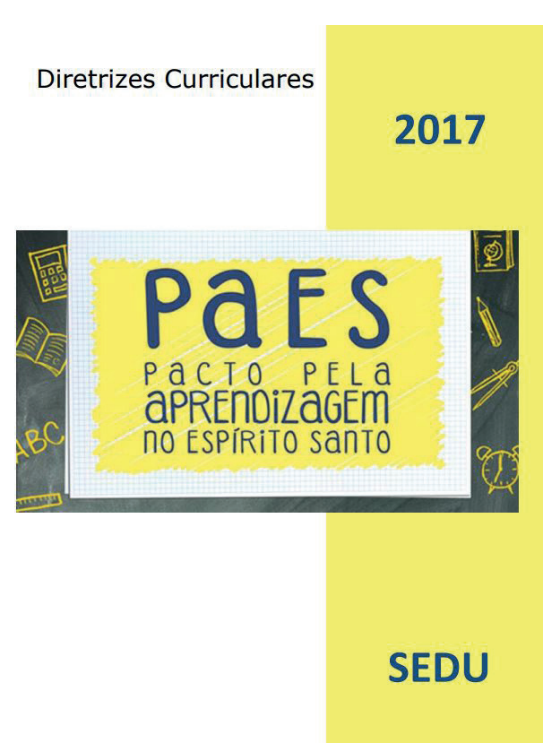

res para Alfabetização

SUMÁRIO

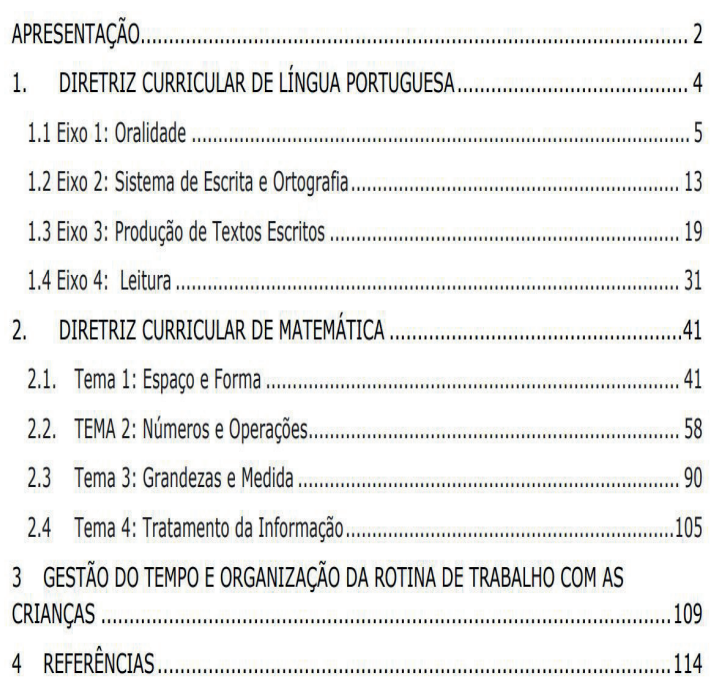

Fonte: Acervo dos autores.

Fonte: Acervo dos autores.

A política indutora de avaliação diagnóstica e os materiais estruturados para serem utilizados por alunos e professores, além de indicarem o cunho regulatório do Paes, demonstra que o programa adota um modelo de formação de profissionais que prioriza a prática docente, o fazer docente, tomando como base uma perspectiva de formação de caráter meramente instrumental. A formação por meio de materiais estruturados facilita treinar os profissionais para aplicar metodologias e homogeneizar o fazer docente nas salas de aulas de escolas públicas estadual e municipais. Portanto, o Paes adere a lógica de professores instrumentalizados com conteúdos que devem ser aplicados, seguindo manuais que definem o quê e como ensinar. Assim, profissionais da educação viram técnicos que dominam a aplicação de conhecimentos científicos produzidos por outros e convertidos em regras a serem seguidas. Logo, é perceptível que o Paes, como uma forma de operacionalizar o regime de colaboração, desconsidera a autonomia pedagógica dos profissionais da educação, sejam a dos gestores de secretarias de educação, sejam a dos professores, por instituir um modelo de colaboração em que a coordenação do estado se organiza em ações centralizadoras e controladoras da prática docente.

Portanto, o diálogo que é mencionado no artigo $1^{\circ}$ da Lei Estadual 10.631/2017 se efetiva como modo de comunicação de formas de operacionalização das ações previstas para cada eixo que integra o Programa e, com isso, o Paes não favorece a gestão democrática e nem a experiência da democracia nas secretarias e nas escolas.

Merece destaque a estreita vinculação das Diretrizes Curriculares adotadas no Paes com a proposta metodológica para a alfabetização contida nos materiais estruturados en- 
viados para as escolas, que se fundamenta na perspectiva denominada de "Alfabetizar Letrando", que, como apontam Gontijo (2005), Gontijo e Schwartz (2009), Gadotti (2011), produz o entendimento de que deve haver uma separação dos processos de aprendizagem da escrita alfabética e das práticas sociais de leitura e de escrita, como descrito em um dos materiais que integram o Kit enviado para as escolas por meio de um esquema explicativo.

Figura 6 - página do Caderno do Professor

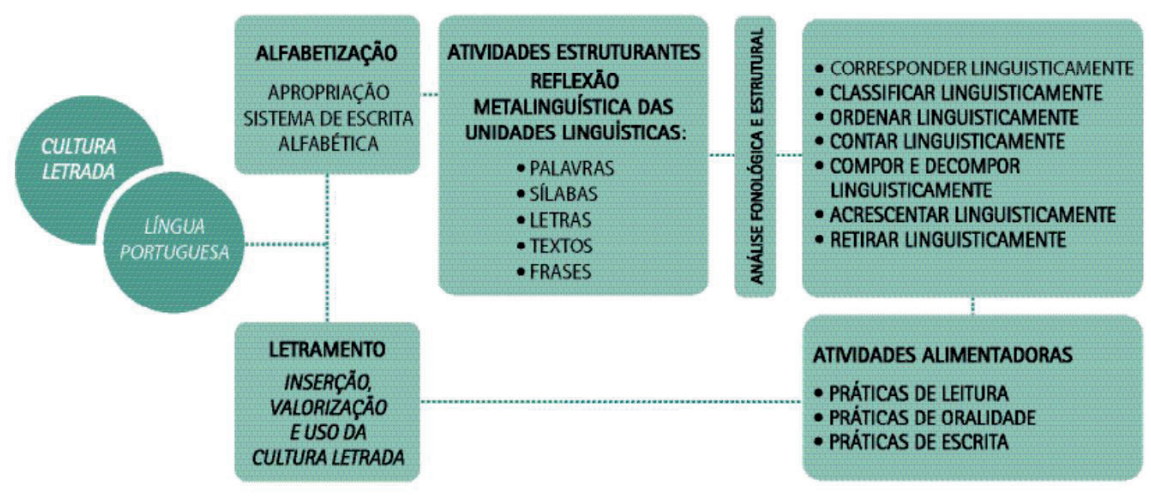

Fonte: Acervo dos autores. 2017.

Assim, o Paes institui uma concepção de alfabetização restrita apenas ao processo de aquisição do sistema de escrita alfabética, limitando-se ao ensino das relações entre fonemas e grafemas a partir de atividades de análise fonológica e estrutural de unidades da língua (palavras, sílabas, letras, frases e textos). Nos materiais que compõem o Kit é visível a centralidade de palavras e frases como unidades privilegiadas para o ensino da leitura e da escrita nos três primeiros meses, demonstrando que a leitura é entendida como uma atividade de decodificação e a escrita de decodificação. Isso se corrobora com a avaliação proposta no caderno de registro do professor em que a avaliação da escrita segue os níveis definidos na Psicogênese da escrita proposta por Ferreiro e Teberoski (1999), o que favorece a quantificação de crianças por níveis de aprendizagens.

Os cadernos de registro dos professores reafirmam que a ênfase da avaliação é a quantificação e a classificação de crianças a partir dos níveis pré-silábica, silábica, silábico-alfabética e alfabética. Vale ressaltar ainda que o kit de materiais apenas possibilita que os profissionais tenham acesso a uma única perspectiva de trabalho com a alfabetização, sonegando a eles o acesso a diferentes teorizações que explicam o processo de apropriação da linguagem escrita pelas crianças.

\section{Considerações finais}

O atual ordenamento jurídico educacional possibilita que regimes de colaboração possam assumir funções reguladoras e centralizadoras de gestão do processo educacional 
desde a sala de aula até as instâncias responsáveis pela organização sistêmica da educação. O Paes é um exemplo de como o governo estadual pode fazer uso do regime de colaboração para operar uma gestão administrativa e pedagógica de controle sob as ações e prática políticas dos municípios.

Mesmo com proposições de melhoria de indicadores educacionais, o programa mostra que, a depender da forma como o regime de colaboração é concebido e de que tipo de arranjo organizacional ele adota, favorece para criar mecanismos de obrigatoriedade para os municípios às avaliações sistêmicas, à uniformização de práticas docentes e à implementação de forma centralizadora e verticalizadora de gestão gerencialista, contribuindo para que os indicadores da qualidade da educação incidam somente sobre resultados de avaliações da aprendizagem.

Desse modo, é possível verificar que a forma de o estado operar o regime de colaboração com os municípios pode induzir a crença de que melhoria da aprendizagem é de responsabilidade apenas do professor e que depende exclusivamente de mudanças da prática docente. Regime de colaboração que parte desse pressuposto induz a adoção pelos Municípios de um modelo único de formação de professores, de organização curricular, de monitoramento de resultados, pela via de avaliações diagnósticas, e da prática docente, por meio de materiais estruturados voltados para o estabelecimento de mecanismos de gestão do tempo e dos espaços pedagógicos em sala de aula.

Nesse sentido, esse tipo de colaboração vertical cerceia a autonomia administrativa e pedagógica das gestões municipais e impõe aos municípios um modelo técnico e instrumental de formação de profissionais e a adoção de perspectivas teóricas do campo da educação que desconsideram os avanços de conhecimento da própria área. A análise do Paes, nessa direção, possibilitou constatar que, a depender da forma como se opera o regime de colaboração, impede-se a introdução de inovações para a gestão da educação pública, pois, ao impor um modelo de gestão, retira a autonomia dos Municípios de formularem suas próprias políticas a partir das demandas e especificidades locais, bem como elimina as possibilidades de os professores e de outros segmentos que compõem a comunidade escolar participarem do processo de formulação de propostas para as escolas.

Acredita-se que um regime de colaboração em que as Secretarias Municipais de Educação são tratadas como executantes de ações previstas pela Secretaria de Estado da Educação e as equipes locais de formação como repassadoras de um modelo pronto de organização da prática pedagógica favorece para que a política de formação dos municípios se transforme em espaçotempo de prescrições de tarefas para as escolas, eliminando a possibilidade de as Secretarias Municipais desenvolverem seu quadro de profissionais autônomos e politicamente conscientes.

Vale chamar atenção ainda para o fato de o regime de colaboração vertical com as características do Paes pode contribuir para que se reeditem, no que diz respeito a base conceitual da alfabetização, antigas concepções que reduzem a alfabetização a mera técnica de ler e escrever no sentido de decodificação (leitura) e codificação (escrita). 
Torna-se importante, também, ressaltar que, se a justificativa para a implementação de regimes de colaboração é o ordenamento jurídico vigente, estado e municípios deveriam primar pelo estabelecimento de relações de interdependência e de corresponsabilidade, próprias do federalismo cooperativo, porém, fundamentadas numa ética pedagógica-política e epistemológica democrática, fazendo-se cumprir também os preceitos legais que asseguram os princípios da gestão democrática e da autonomia pedagógica. Como apontado no pensamento Freiriano, a democracia pode ser entendida como respeito as individualidades e singularidades humanas, o que significaria, no caso de implementação de regimes de colaboração, considerar as experiências acumuladas nos municípios pelos profissionais que lá atuam.

Por fim, conclui-se que, como o regime de colaboração foi a aposta para diminuir desigualdades no que tange ao direito a educação e a igualdade de condições, programas criados para implementar a colaboração, obrigatoriamente, deveriam se voltar para interferir em temas como democracia e igualdade e, como tal, colocar em prática uma forma de operacionalizar a descentralização por meio de ações dialógicas que oportunizassem a participação de diferentes segmentos da educação na formulação de políticas voltadas para a melhoria da educação, bem como oportunizar a participação da sociedade civil nas políticas educacionais. 


\section{Referências}

ABRUCIO, Fernando Luiz; SEGATTO, Catarina lanni; PEREIRA, Maria Cecília Gomes. Regime de colaboração no Ceará: funcionamento, causas do sucesso e alternativas de disseminação do modelo. São Paulo: Instituto Natura, 2017. Disponível em: < http://www.institutonatura.org.br/wp-content/uploads/2016/12/Relatorio-Ceara-AF-Web.pdf>. Acesso em: 06 jan 2019.

ABRUCIO, Fernando Luiz. A dinâmica federativa da educação brasileira: diagnóstico e propostas de aperfeiçoamento. In: OLIVEIRA, Romualdo Portela de; SANTANA, Wagner (Org.). Educação e federalismo no Brasil: combater as desigualdades, garantir a diversidade. Brasília: UNESCO, 2010. p. 39-70.

ABRUCIO, Fernando Luiz. Descentralização e Coordenação federativa no Brasil: lições dos anos FHC. In: ABRUCIO, Fernando Luiz; LOUREIRO, Maria Rita Gomes. O Estado numa era de reformas: Os anos FHC - Parte 2. Brasília: MP/SEGES. 2002.

ADRIAO, Theresa et al. Uma modalidade peculiar de privatização da educação pública: a aquisição de "sistemas de ensino" por municípios paulistas. Educ. Soc., Campinas, v. 30, n. 108, p.799-818, Oct. 2009. Available from <http://www.scielo.br/scielo.php?script=sci_arttext\&pid=S010173302009000300009\&Ing=en\&nrm=iso >. Access on 19 Mar. 2019. http://dx.doi. org/10.1590/S0101-73302009000300009.

ARAUJO, G. C. Direito à educação básica: a cooperação entre os entes federados. Revista Retratos da Escola, Brasília, v. 4, n. 7. p. 231-243. Jul/dez. 2010. Disponível em <http //www.esforce.org. br>. Acesso em: 5 jan 2019.

ARAUJO, G. C. Federalismo e políticas educacionais no Brasil: equalização e atuação do empresariado como projetos em disputa para a regulamentação do regime de colaboração. Educ. Soc. [online]. 2013, vol. 34, n. 124, p.787-802. ISSN 0101-7330. http://dx.doi.org/10.1590/ S0101-73302013000300008.

ARAUJO, G. C.; RODRIGUES, R. F.; CASSINI, S. A. Federalismo e políticas educacionais: notas sobre aspectos jurídicos-políticos e fiscais-financeiros nas relações intergovernamentais. In: ARAUJO, G. C.; RODRIGUES, R. F. (Org.); Federalismo e políticas educacionais: entre velhos dilemas e novos desafios. Rio de Janeiro: Brasil Multicultural, 2018, p. 24-37.

BAKHTIN, M. M. Estética da criação verbal. São Paulo: Martins Fontes, 2003.

BAKHTIN, M. M. Marxismo e filosofia da linguagem. São Paulo: Hucitec, 2004.

BONAMINO, Alice Maria Catalano de. O público e o privado na educação brasileira. Revista brasileira de história da educação. Campinas, n. 5. p. 253-276, jan./jun. 2003.

Tempos de avaliação educacional: o SAEB, seus agentes, referências e tendências. Rio de Janeiro: Quartet, 2002.

BONAMINO, A.; SOUSA, S. Z. Três gerações de avaliação da educação básica no Brasil: interfaces com o currículo da/na escola. Educ. Pesqui., São Paulo, v. 38, n. 2, p. 373388, June 2012. Available from <https://www.scielo.br/scielo.php?script=sci_arttext\&pi- 
d=S1517-97022012000200007\&Ing=en\&nrm=iso>. access on 01 July 2018. Epub Feb 14, 2012. http://dx.doi.org/10.1590/S1517-97022012005000006.

BORDIGNON, Genuíno; GRACINDO, Regina Vinhaes. Gestão da educação: município e escola. IN: FERREIRA, N. S. e AGUIAR, M. A. (Orgs.). Gestão da Educação: impasses, perspectivas e compromissos. São Paulo: Cortez, 2002.

BRASIL. Constituição da República Federativa do Brasil, de 05 de outubro de 1988. Disponível em: <www.planalto.gov.br/ccivil 03/constituicao/constituicaocompilado.htm>. Acesso em: 03 fev 2019.

BRASIL. Decreto $n^{\circ}$ 6.094, de 24 de abril de 2007. Disponível em: < http://www.planalto.gov.br/ccivil 03/ ato2007-2010/2007/decreto/d6094.htm>. Acesso em: 05 fev 2019.

BRASIL. Constituição (1988). Emenda Constitucional n 53, de 19 de dezembro de 2016. Disponível em:

<http://www.planalto.gov.br/ccivil_03/Constituicao/Emendas/Emc/emc53.htm>. Acesso em:

02 fev 2019.

BRASIL. Lei no 13.005, de 25 de junho de 2014. Aprova o Plano Nacional de Educação (PNE) e dá outras providências. Brasília: Câmara dos Deputados, Edições Câmara, 2014. 86 p.

BRASIL. Lei n 9.394 de dezembro de 1996. Dispõe sobre as Diretrizes e Bases da Educação Nacional. Disponível em:http://www.planalto.gov.br/civil_03/Constituicao/Constituiçao.htm. Acesso em: 13 abr. 2018.

CASSINI, Simone Alves. Federação e Educação no Brasil: a atuação do poder legislativo nacional para regulamentação do regime de colaboração. 2011. 143f. Dissertação (Mestrado em Educação) - Programa de Pós-Graduação em Educação, Universidade Federal do Espírito Santo, Vitória, 2011.

COSTA, A. C. O regime de colaboração entre União, estados e municípios no financiamento da educação no Brasil. Revista Brasileira de Política e Administração da Educação, Brasília, v. 26, n. 1. p. 105-121. Jan/abr. 2010. Disponível em:< https://seer.ufrgs.br/rbpae/article/view/19685/11469>. Acesso em: 10 jan 2019.

COSTA, A., VIDAL, E., \& VIEIRA, S. Avaliação em larga escala no Brasil. Revista Educação Em Questão, v. 57, n. 51, p. 01-29. jan/mar. 2019. Disponível em < https://periodicos.ufrn.br/educacaoemquestao/article/view/15806>. Acesso em: 04 jan 2019.

CUNHA, Luis Antonio. Educação, Estado e Democracia no Brasil. São Paulo: Cortez, 1991.

CURY, Carlos Roberto Jamil. Por um novo plano nacional de educação. Cad. Pesqui., São Paulo , v. 41, n. 144, p. 790-811, Dec. 2011. Available from <http://www.scielo.br/scielo.php?script=sci_arttext\&pid=S0100-15742011000300008\&Ing=en\&nrm=iso>. access on 18 Mar. 2019. http:// dx.doi.org/10.1590/S0100-15742011000300008.

CURY, C.R. Jamil. O Conselho Nacional de Educação e a Gestão Democrática. Rio de Janeiro, Vozes, 1997. In: OLIVEIRA, Dalila (Org.). Gestão democrática da educação: desafios contemporâneos. Rio de Janeiro: Vozes, 1997. 
CURY, Carlos Roberto Jamil. A questão federativa e a educação escolar. In: OLIVEIRA, Romualdo Portela de; SANTANA, Wagner (Org.). Educação e federalismo no Brasil: com- bater as desigualdades, garantir a diversidade. Brasília: Unesco, 2010.

DEFOURNY, Vicent. Prefácio. In: OLIVEIRA, Romualdo Portela de; SANTANA, Wagner (Org.). Educação e federalismo no Brasil: combater as desigualdades, garantir a diversidade. Brasília: UNESCO, 2010.

DOURADO, Luiz Fernandes. Sistema Nacional de Educação, Federalismo e os obstáculos ao direito à educação básica. Educ. Soc., Campinas, v.34, n. 124, p.761-785, Sept. 2013. Available from <http:// www.scielo.br/scielo.php?script=sci_arttext\&pid=S0101-73302013000300007\&lng=en\&nrm=iso>. access on 18 Mar. 2019. http://dx.doi.org/10.1590/S0101-73302013000300007.

DUARTE, Clarice Seixas. Direito público subjetivo e políticas educacionais. São Paulo Perspec., São Paulo, v. 18, n. 2, p. 113-118, June 2004. Available from <http://www.scielo.br/scielo.php?script=sci_arttext\&pid=S0102-88392004000200012\&Ing=en\&nrm=iso > . access on 18 Mar. 2019. http://dx.doi.org/10.1590/S0102-88392004000200012.

ESPÍRITO SANTO. Secretaria de Estado da Educação. Diretrizes para a Alfabetização. 2017a. $15 p$.

ESPÍRITO SANTO. Lei no 10.382, de 24 de junho de 2015. Aprova o Plano Estadual de Educação do Espírito Santo - PEE/ES (2015/2025). Vitória: Governo do Estado, [2015]. Disponível em: < http://www3.al.es.gov.br/Arquivo/Documents/legislacao/html/10.382.htm>. Acesso em: 01 fev 2019.

ESPÍRITO SANTO. Lei $\mathbf{n}^{\circ} \mathbf{1 0 . 6 3 1}$, de 28 de março de 2017. Institui o Pacto pela Aprendizagem no Espírito Santo e dá outras providências. Vitória: Governo do Estado, [2017b]. Disponível em:< http://www3.al.es.gov.br/Arquivo/Documents/legislacao/html/LEl106312017.html>. Acesso em: 02 fev 2019.

ESPÍRITO SANTO. Lei $\mathbf{n}^{\circ} \mathbf{1 0 . 7 8 7}$, de 18 de dezembro de 2017. Institui o Fundo Estadual de Apoio à Ampliação e Melhoria das Condições de Oferta da Educação Infantil no Espírito Santo e dá outras providências. Vitória: Governo do Estado, [2017c]. Disponível em: < http://www3.al.es.gov.br/Arquivo/Documents/legislacao/html/LEl107872017.html>. Acesso em: 02 fev 2019.

ESPÍRITO SANTO. Secretária de Estado da Educação. Oficio 04/COPAES. Vitória, ES: Secretaria de Educação do Estado do Espírito Santo, 02 fev 2018. Assunto: Cronograma de Avaliação Diagnóstica.

ESPÍRITO SANTO (Estado). Secretária de Estado da Educação. Projeto básico para Execução do Pacto pela Aprendizagem do Espírito Santo - PAES. 2017d. 25p.

ESPÍRITO SANTO (Estado). Secretaria de Estado da Educação. Pacto pela aprendizagem no Espírito Santo. Disponível em: <https://sedu.es.gov.br/paes>. 2017e. Acesso em: 10 jan 2019.

FERNANDES, T. W. P. Regime de colaboração: o contexto histórico das ações e das práticas em educação. Revista Educação em Foco, Juiz de Fora, v. 17, n. 3. p. 153-176. Nov/fev. 2013. Disponível em: <https://www.ufjf.br/revistaedufoco/files/2013/10/cap-07.pdf>. Acesso em: 3 fev 2019.

FERREIRO, Emília; TEBEROSKY, Ana. Psicogênese da língua escrita. Porto Alegre: Artmed, 1999. 
FREIRE, Paulo. Cartas a Cristina. Rio de Janeiro: Paz e Terra. 1994.

FREIRE, Paulo. Pedagogia da Autonomia: Saberes Necessários à Prática Educativa. 2. ed. São Paulo: Paz e Terra, 1996.

FREIRE, Paulo. Pedagogia do Oprimido. 10. ed. Rio de Janeiro: Paz e Terra, 1981.

FREIRE, Paulo. Política e Educação. 5. ed. São Paulo: Cortez, 2001.

GADOTTI, Moacir. Prefácio: alfabetização e letramento - como negar nossa história? In: ZACCUR, Edwiges Guiomar dos Santos. (Org.). Alfabetização e letramento: o que muda quando muda o nome? Rio de Janeiro: Rovelle, 2011.

Gestão democrática com participação popular: no planejamento e na organização da educação nacional. Disponível em: <http://conae2014.mec.gov.br/images/pdf/artigogadotti_final.pdf. >. Acesso em: 03 fev 2019.

GONTIJO, Cláudia Maria Mendes. Alfabetização e a questão do letramento. Cadernos de Pesquisa, Universidade Federal do Espírito Santo, Centro de Educação, Programa de Pós-Graduação em Educação, Vitória: PPGE, v. 11, n. 21, p. 42-72, jan./jun. 2005.

GONTIJO, Cláudia Maria Mendes; SCHWARTZ, Cleonara Maria. Alfabetização: teoria e prática. Curitiba: Sol, 2009.

HORA, Dinair Leal da. Gestão democrática na escola: artes e ofícios da participação coletiva. Campinas: Papiros, 1996.

LIBÂNEO, José Carlos at al. Educação escolar: políticas, estrutura e organização. São Paulo: Cortez, 2003.

LIBÂNEO, José Carlos. Educação escolar, políticas, estruturas e organização. 2 ed. SP: Cortez, 2005.

LIMA, Licínio C. Organização escolar e democracia radical: Paulo Freire e a governação democrática da escola pública. 2.ed. São Paulo: Cortez: Instituto Paulo Freire, 2002.

MOEHLECKE, S. O ensino médio e as novas diretrizes curriculares nacionais: entre recorrências e novas inquietações. Revista Brasileira de Educação. Campinas. v. 17 n. 49 jan.-abr. 2012.

NASCIMENTO, R. P.; ALVES, S. L. S.; FERRARI, L. Federalismo: interfaces na (des)integração do regime de colaboração e do Sistema Nacional de Educação. In: ARAUJO,

G. C.; RODRIGUES, R. F. (Org.); Federalismo e políticas educacionais: entre velhos dilemas e novos desafios. Rio de Janeiro: Brasil Multicultural, 2018, p. 82-101.

OLIVEIRA, Maria Auxiliadora Monteiro. Gestão Educacional: novos olhares, novas abordagens. Petrópolis: Vozes, 2005, 119p.

OLIVEIRA, Romualdo Portela de; SANTANA, Wagner (Org.). Educação e federalismo no Brasil: combater as desigualdades, garantir a diversidade. Brasília: UNESCO, 2010. 
PARO, Vitor Henrique. Eleição de diretores: a escola pública experimenta a democracia. Campinas, Papirus, 1995.

PARO, Vitor Henrique. Gestão democrática da escola pública. São Paulo: Ática, 1997.

PARO, Vitor Henrique. Gestão escolar, democracia e qualidade do ensino. - São Paulo: Ática, 2007.

SANDER, B. Políticas Públicas e Gestão Democrática da Educação. Brasília. Líber Livro Editora, 2005.

SAVIANI, D. Educação brasileira: estrutura e sistema. Campinas: Autores Associados, 2008.

SENA, P. A concretização do regime de colaboração. In: ARAUJO, G. C.; RODRIGUES, R. F. (Org.); Federalismo e políticas educacionais: entre velhos dilemas e novos desafios. Rio de Janeiro: Brasil Multicultural, 2018, p. 52-61.

SOUSA; K.; CASTRO, A. Federalismo cooperativo e Plano de Ações Articuladas (PAR) - Algumas aproximações teóricas. Ensaio: aval. pol. públ. Educ., Rio de Janeiro, v.25, n. 97, p. 874-896, out/ dez. 2017.

SOUZA, D.; FARIA, L. Reforma do Estado, Descentralização e Municipalização do Ensino no Brasil: A Gestão Política dos Sistemas Públicos de Ensino Pós-LDB 9.394/96. Ensaio: aval. pol. públ. Educ., Rio de Janeiro, v.12, n.45, p. 925-944, out./dez. 2004.

XAVIER, L. Oscilações do público e do privado na história da educação brasileira. Revista Brasileira De História Da Educação. V. 3. N. 5. P. 233-251, jan./jun. 2003. 